\title{
FORMATION OF A SYSTEM OF MULTICRITERIA INDICATORS FOR THE ASSESSMENT OF OFFICE LEASING OPTIONS
}

\author{
Tomas GINEVIČIUS a , Ilona SKAČKAUSKIENE் a,*, Andrius STASIUKYNAS b, Izolda JOKŠIENE் b \\ ${ }^{a}$ Department of Social Economics and Management, Vilnius Gediminas Technical University, \\ Sauletekio al. 11, LT-10223 Vilnius, Lithuania \\ ${ }^{b}$ Department of Economics and Management of Enterprises, Vilnius Gediminas Technical University, \\ Sauletekio al. 11, LT-10223 Vilnius, Lithuania
}

Received 8 April 2016; accepted 12 June 2016

\begin{abstract}
With the growing scope of business and the internationalization of companies, office leasing is becoming an increasingly relevant issue. It has become an integral part of business and affects the results of commercial activities. The methods for the assessment of office leasing options that are available at the moment are imperfect, as they lack complexity and they are not related to the objective of the lease - the improvement of business results, imperfect methods for a quantitative assessment of the lease options, etc. The adequacy of the assessment of lease options largely depends on the system of indicators that is used. The system is formed on the basis of a list of indicators composed from different sources. For the system of indicators to fully reflect the analyzed phenomenon and to be suitable for a quantitative assessment, there have to be not too many or too few indicators in the system. This means that the indicators that are insignificant have to be eliminated from the list. The most precise way to do that is to apply methods of mathematical statistics. The research is based on the analysis of scientific literature and the methods of mathematical statistics.
\end{abstract}

KEYWORDS: Lease of offices; Indicators of lease options; Formation of a system of indicators; Multicriteria assessment; Expert assessment

\section{INTRODUCTION}

The formation of the system of indicators has a special role in multicriteria assessments. This is because the adequacy of the reflection of the analyzed phenomenon depends on this system. Despite its importance, this phase of the multicriteria assessment is not given enough attention. In some cases, the system of indicators is simply identified with a pre-formed list of indicators; and in other, where the question of eliminating or keeping certain indicators in the system is analyzed, it is done without a sufficiently methodical basis.

The list of indicators reflecting the analyzed phenomenon (AP) usually covers a potentially high number of indicators (Podvezko 2008; Zavadskas, Turskis 2011). It is considered that the more extensive the list, the better the AP is reflected. Secondly, the indicators on the list are not equally important to the analyzed phenomenon - some of

${ }^{1}$ Corresponding author. E-mail: ilona.skackauskiene@vgtu.lt them are insignificant. Such indicators should not be included in the system, which is the basis for the AP assessment, as they will not increase the accuracy of the assessment, but will significantly encumber the calculations. Thus, insignificant indicators should be eliminated. Generally, the following statements are followed when forming a system for a multicriteria assessment based on a list of indicators (Ginevičius, Podvezko 2005): first of all, the more indicators that are included into the system, the more accurate the reflection of the analyzed phenomenon will be; and conversely, the fewer indicators that are included into the system, the higher the risk is that significant AP indicators will remain unanalyzed and the assessment of the state of the AP may prove to be inadequate. Secondly, the more indicators that are included, the more indicators there will be that are difficult to formalize, and besides the system becoming more complex, it will be more difficult to accurately determine the significance of the indicators. As a 
result, the cost of the calculations will increase, and their accuracy will decrease. This leads to the conclusion that the number of indicators included into the system cannot be too low or too high.

An analysis of the sources of literature shows that there are two possible methods of forming a system of indicators. The first one is limited to those indicators mentioned most often in the sources of literature and other sources (Brauers et al. 2014; Ginevičius, Podvezko 2013; Nugaras, Ginevičius 2015). It is the most basic, but also a less accurate method. The second method uses the more complex but significantly more accurate methods of mathematical statistics (Ginevičius, Podvezko 2005; Ginevičius et al. 2013; Kondyli 2010; Boggia, Cortina 2010; Buracas et al. 2012; Mardani et al. 2015a, 2015b; Kim et al. 2015; Bausys, Zavadskas 2015; Keshavarz Ghorabaee et al. 2015; Hashemkhani Zolfani et al. 2016; Liu et al. 2016; Kou et al. 2016).

The aim of the article is to form a system of indicators for the leasing of commercial real estate objects (offices) from a list compiled by applying the methods of mathematical statistics. The research is based on an analysis of the scientific literature and on the methods of mathematical statistics.

\section{FORMATION OF THE SYSTEM OF INDICATORS BY APPLYING THE METHODS OF MATHEMATICAL STATISTICS}

An analysis of the sources of literature allows us to distinguish certain typical methods of the formation of a list of indicators for the analyzed phenomenon. In the simplest cases, indicators are included in the list without any justification. It would seem that the author bases their inclusion solely on his/ her opinion; therefore, this is the most subjective way of forming a list (Azbainis, Rudzkienè 2011). The most common cases are when the list is based solely on the sources of literature (Russell 2002; Turskis et al. 2009; Ball et al. 2012; Pagourtzi et al. 2003; Golusin, Munitlak Ivanović 2009). The third method, which is rather rare, is when the list of indicators is based on an expert assessment. Another rare method is when a list is formed on the basis of the sources of literature and other sources, as well as expert assessment (French, Wiseman 2003; Nase et al. 2013; Joksiene, Zvirblis 2014).

The latter is the best method, as it evaluates international experience, and, thanks to the expert assessment also takes into consideration the specific aspects of the country where the research is taking place.

This article is based on this method of the formation of the list of indicators for the analyzed phenomenon. In any event, an initial table has been drawn up for the list of AP indicators highlighting the indicators most often mentioned or suggested in the sources of literature (Čeh et al. 2012; Nase et al. 2013; Au-Yong et al. 2014) as well as by the experts (Table 1).

Based on the sources of literature and other sources, as well as the opinions of 21 experts, Table 1 has been drawn up. 59 indicators were defined. All of them could be divided into three blocks according to their similarities: economic indicators - 14; indicators describing the atmosphere and potential of the premises -27 ; and indicators describing the infrastructure of the environment and location - 18 (Fig. 1).

Table 1. Initial table for the formation of the system of indicators for the analyzed phenomenon

\begin{tabular}{|c|c|c|c|c|c|c|c|c|}
\hline \multirow[t]{2}{*}{ No. } & \multirow[t]{2}{*}{ Name of source } & \multicolumn{7}{|c|}{ Indicators } \\
\hline & & $1^{\mathrm{st}}$ & $2^{\text {nd }}$ & $3^{\text {rd }}$ & $\ldots$ & $i^{\text {th }}$ & $\ldots$ & $n^{\text {th }}$ \\
\hline 1 & & + & & + & $\ldots$ & & $\ldots$ & + \\
\hline 2 & & + & + & + & $\ldots$ & + & $\ldots$ & \\
\hline 3 & & & & + & $\ldots$ & + & $\ldots$ & + \\
\hline . & & . & . & . & . & . & $\cdots$ & \\
\hline$\cdot$ & & $\cdot$ & $\cdot$ & $\cdot$ & $\cdot$ & $\cdot$ & & \\
\hline$\cdot$ & & $\cdot$ & $\cdot$ & $\cdot$ & $\cdot$ & $\cdot$ & & \\
\hline I & & + & & + & $\ldots$ & & $\ldots$ & + \\
\hline . & & $\cdot$ & $\cdot$ & $\cdot$ & $\cdots$ & $\cdot$ & $\cdots$ & $\cdot$ \\
\hline$\cdot$ & & $\cdot$ & $\cdot$ & $\cdot$ & & $\cdot$ & & · \\
\hline$\cdot$ & & $\cdot$ & $\cdot$ & $\cdot$ & & $\cdot$ & & $\cdot$ \\
\hline$M$ & & + & & + & & & & + \\
\hline & Total & $\Gamma$ & $\Gamma$ & $\Gamma$ & $\cdots$ & $\Gamma$ & $\cdots$ & $\Gamma$ \\
\hline
\end{tabular}




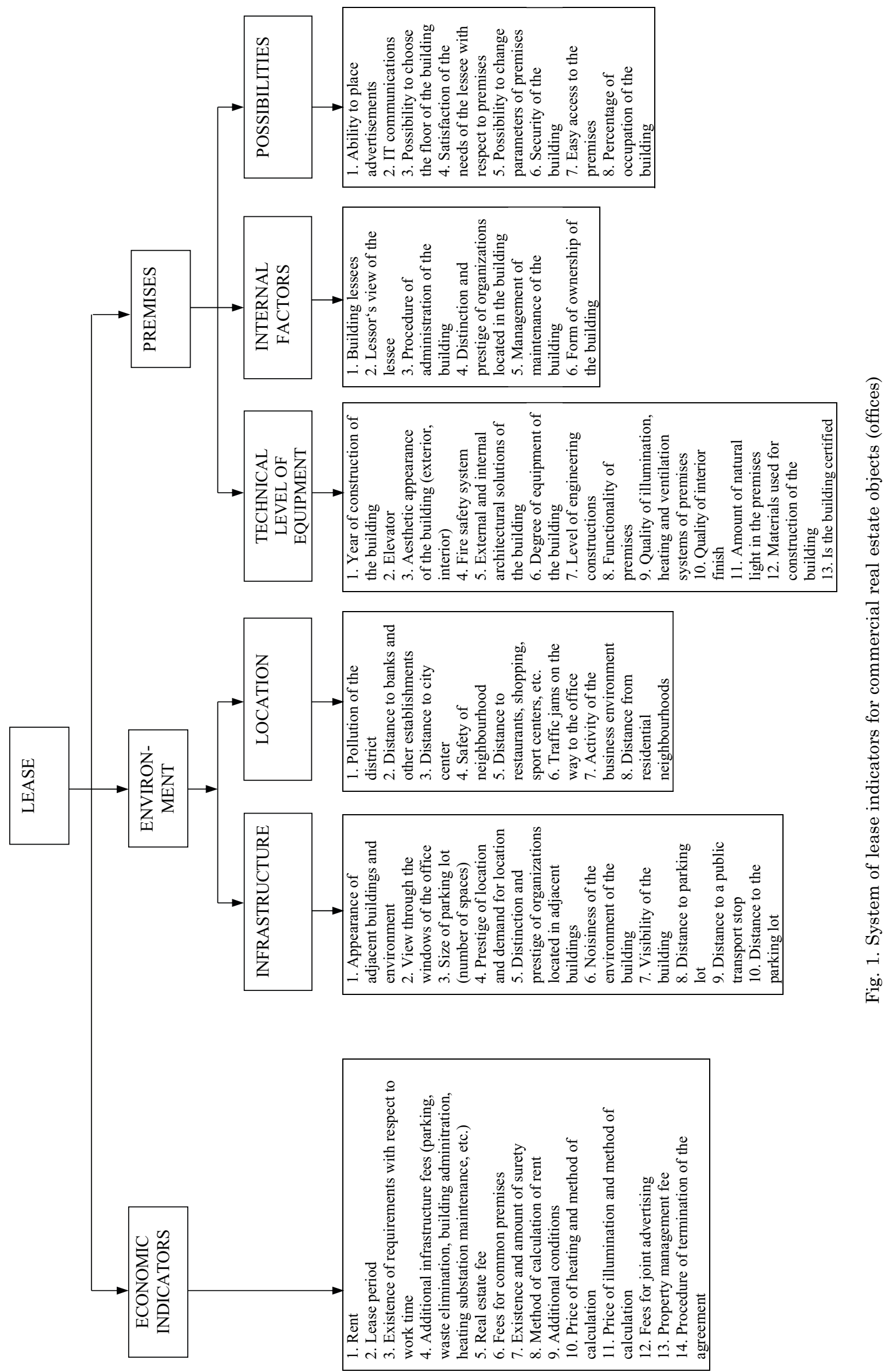


Such a grouping helps the experts to adequately rank the indicators according to their importance. The elimination of insignificant indicators is based on a histogram obtained by placing the indicators at respective intervals, according to their rate of mentioning, i.e. their rank. Its configuration is thus also the theoretical probability distribution of a random value $X$, whose description largely depends on the manner of grouping the ranks of the indicators. In order to draw up a histogram, first of all we need to rank the indicators of all three blocks, according to their importance. Rank 1 is given to the most important indicator and rank $n$ - to the least important indicator (where $n$ is the number of indicators in a block). In our case, the value $X$ shows the number of times the same rank of the indicator was given in the questionnaires by the experts. Interval $\left[X_{i-1} . X_{i} J_{F}\right]$ shows that indicators $n_{i}$ were mentioned in all questionnaires by the experts from $i-1$ to $i$ times, e.g. [0.6], $n_{i}=4$. This shows that 4 indicators were mentioned in all questionnaires from 0 to 5 times (6 is not covered by the interval). The results of the ranking of all three blocks of lease indicators - economic, environment and premises - are presented in Tables 2-4.

Table 2. Results of the ranking of importance of the economic lease indicators

\begin{tabular}{|c|c|c|c|c|c|c|c|c|c|c|c|c|c|c|c|c|c|c|c|c|c|c|c|}
\hline No. & Name of indicator & $\operatorname{Exp}$ & perts & & & & & & & & & & & & & & & & & & & & Total \\
\hline 1. & Rent & 1 & 1 & 1 & 2 & 1 & 1 & 1 & 1 & 2 & 2 & 2 & 2 & 2 & 1 & 1 & 1 & 1 & 1 & 1 & 1 & 1 & 27 \\
\hline 2. & Lease period & 14 & 12 & 13 & 14 & 13 & 14 & 14 & 12 & 13 & 12 & 13 & 13 & 14 & 14 & 14 & 11 & 11 & 14 & 12 & 13 & 13 & 273 \\
\hline 3. & $\begin{array}{l}\text { Existence of } \\
\text { requirements with } \\
\text { respect to work time }\end{array}$ & 13 & 11 & 14 & 10 & 14 & 10 & 13 & 13 & 10 & 10 & 8 & 8 & 9 & 12 & 10 & 10 & 14 & 11 & 14 & 14 & 12 & 240 \\
\hline 4. & $\begin{array}{l}\text { Additional } \\
\text { infrastructure fees } \\
\text { (parking, waste } \\
\text { elimination, building } \\
\text { administration, } \\
\text { heating substation } \\
\text { maintenance, etc.) }\end{array}$ & 3 & 2 & 2 & 1 & 5 & 2 & 3 & 2 & 3 & 1 & 1 & 1 & 1 & 1 & 9 & 2 & 2 & 2 & 2 & 2 & 3 & 51 \\
\hline 5. & Real estate fee & 7 & 6 & 6 & 7 & 3 & 5 & 6 & 3 & 5 & 5 & 4 & 4 & 3 & 8 & 4 & 7 & 6 & 5 & 4 & 8 & 8 & 114 \\
\hline 6. & $\begin{array}{l}\text { Fees for common } \\
\text { premises }\end{array}$ & 12 & 9 & 9 & 11 & 12 & 7 & 12 & 9 & 11 & 14 & 12 & 12 & 10 & 10 & 9 & 9 & 12 & 13 & 11 & 9 & 7 & 220 \\
\hline 7. & $\begin{array}{l}\text { Method of calculation } \\
\text { of rent }\end{array}$ & 6 & 8 & 11 & 6 & 8 & 4 & 10 & 10 & 8 & 7 & 11 & 11 & 7 & 11 & 8 & 8 & 10 & 9 & 10 & 5 & 6 & 174 \\
\hline 8. & $\begin{array}{l}\text { Existence and amount } \\
\text { of surety }\end{array}$ & 5 & 10 & 4 & 8 & 6 & 11 & 11 & 5 & 6 & 11 & 3 & 5 & 4 & 4 & 6 & 3 & 4 & 7 & 7 & 6 & 4 & 130 \\
\hline 9. & Additional conditions & 9 & 14 & 10 & 12 & 7 & 9 & 8 & 6 & 12 & 13 & 10 & 10 & 13 & 13 & 11 & 12 & 13 & 12 & 13 & 11 & 5 & 222 \\
\hline 10. & $\begin{array}{l}\text { Price of heating and } \\
\text { method of calculation }\end{array}$ & 10 & 5 & 5 & 13 & 4 & 13 & 7 & 7 & 7 & 4 & 7 & 7 & 6 & 7 & 12 & 14 & 8 & 6 & 9 & 12 & 11 & 174 \\
\hline 11. & $\begin{array}{l}\text { Price of illumination } \\
\text { and method of } \\
\text { calculation }\end{array}$ & 8 & 7 & 12 & 5 & 9 & 3 & 2 & 8 & 9 & 6 & 9 & 9 & 11 & 5 & 3 & 4 & 9 & 3 & 6 & 7 & 9 & 144 \\
\hline 12 . & $\begin{array}{l}\text { Fees for joint } \\
\text { advertising }\end{array}$ & 2 & 3 & 7 & 4 & 2 & 6 & 5 & 4 & 1 & 3 & 5 & 3 & 5 & 2 & 5 & 5 & 3 & 4 & 3 & 3 & 2 & 77 \\
\hline 13. & $\begin{array}{l}\text { Property management } \\
\text { fee }\end{array}$ & 4 & 13 & 8 & 9 & 10 & 12 & 9 & 14 & 14 & 9 & 14 & 14 & 12 & 6 & 13 & 13 & 7 & 8 & 8 & 10 & 14 & 221 \\
\hline 14. & $\begin{array}{l}\text { Procedure of } \\
\text { termination of the } \\
\text { agreement }\end{array}$ & 11 & 4 & 3 & 3 & 11 & 8 & 4 & 11 & 4 & 8 & 6 & 6 & 8 & 3 & 7 & 6 & 5 & 10 & 5 & 4 & 10 & 137 \\
\hline
\end{tabular}

Table 3. Results of ranking of importance of premises lease indicators

\begin{tabular}{|c|c|c|c|c|c|c|c|c|c|c|c|c|c|c|c|c|c|c|c|c|c|c|c|}
\hline No. & Name of indicator & $\operatorname{Exp}$ & erts & & & & & & & & & & & & & & & & & & & & Total \\
\hline 1. & $\begin{array}{l}\text { Year of construction of } \\
\text { the building }\end{array}$ & 21 & 26 & 17 & 16 & 16 & 11 & 25 & 27 & 12 & 27 & 24 & 11 & 4 & 4 & 18 & 16 & 12 & 25 & 20 & 22 & 19 & 373 \\
\hline 2. & Elevator & 23 & 14 & 22 & 13 & 11 & 10 & 17 & 13 & 20 & 10 & 20 & 20 & 21 & 27 & 7 & 18 & 13 & 6 & 23 & 21 & 16 & 339 \\
\hline 3. & $\begin{array}{l}\text { Aesthetic appearance } \\
\text { of the building } \\
\text { (exterior, interior) }\end{array}$ & 4 & 6 & 5 & 12 & 12 & 15 & 16 & 11 & 17 & 11 & 17 & 25 & 1 & 1 & 3 & 5 & 15 & 11 & 14 & 1 & 9 & 201 \\
\hline
\end{tabular}




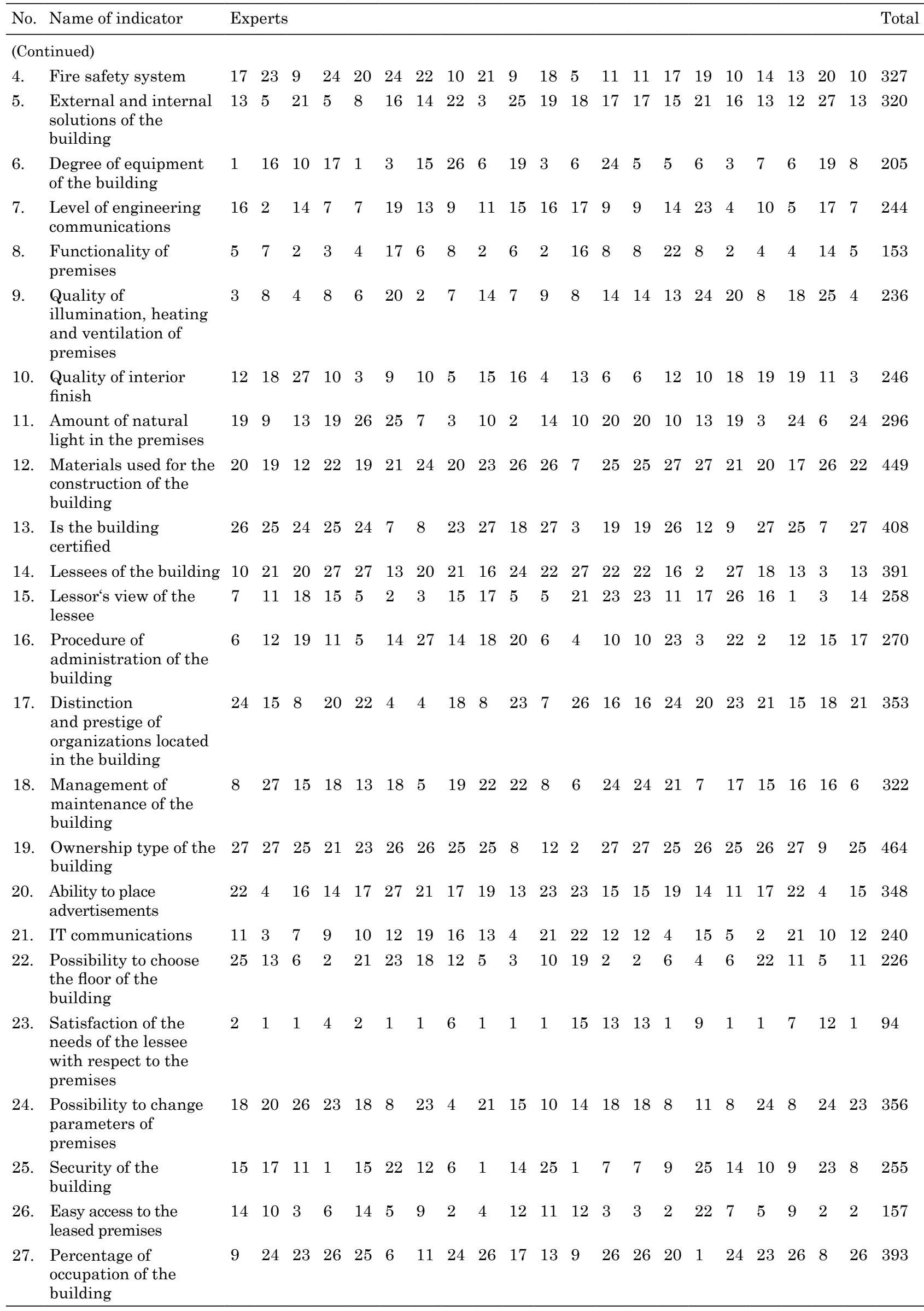


Table 4. Results of ranking of importance of environment indicators

\begin{tabular}{|c|c|c|c|c|c|c|c|c|c|c|c|c|c|c|c|c|c|c|c|c|c|c|c|}
\hline No. & Name of indicator & Ex] & perts & & & & & & & & & & & & & & & & & & & & Total \\
\hline 1. & $\begin{array}{l}\text { Pollution of the } \\
\text { district }\end{array}$ & 17 & 9 & 7 & 7 & 16 & 17 & 9 & 6 & 4 & 5 & 12 & 1 & 18 & 16 & 3 & 17 & 18 & 14 & 1 & 18 & 4 & 221 \\
\hline 2. & $\begin{array}{l}\text { Appearance of } \\
\text { adjacent buildings } \\
\text { and environment }\end{array}$ & 6 & 8 & 9 & 5 & 10 & 13 & 10 & 14 & 13 & 3 & 11 & 3 & 9 & 4 & 1 & 9 & 15 & 7 & 13 & 2 & 13 & 185 \\
\hline 3. & $\begin{array}{l}\text { Distance to banks and } \\
\text { other establishments }\end{array}$ & 18 & 13 & 10 & 12 & 4 & 2 & 13 & 7 & 16 & 2 & 10 & 15 & 8 & 8 & 3 & 10 & 6 & 10 & 14 & 6 & 11 & 200 \\
\hline 4. & $\begin{array}{l}\text { Size of parking lot } \\
\text { (number of spaces) }\end{array}$ & 12 & 17 & 11 & 15 & 18 & 15 & 17 & 18 & 12 & 12 & 13 & 14 & 10 & 7 & 1 & 11 & 9 & 18 & 15 & 15 & 14 & 276 \\
\hline 5. & $\begin{array}{l}\text { Distance to } \\
\text { residential } \\
\text { neighbourhoods }\end{array}$ & 13 & 18 & 3 & 17 & 17 & 18 & 12 & 17 & 18 & 7 & 18 & 4 & 13 & 6 & 18 & 15 & 17 & 16 & 17 & 14 & 12 & 292 \\
\hline 6. & Distance to city centre & 1 & 16 & 1 & 11 & 9 & 6 & 16 & 16 & 7 & 2 & 9 & 10 & 11 & 3 & 12 & 7 & 5 & 5 & 16 & 5 & 8 & 178 \\
\hline 7. & $\begin{array}{l}\text { Security of the } \\
\text { neighbourhood }\end{array}$ & 3 & 3 & 8 & 9 & 11 & 8 & 15 & 4 & 11 & 6 & 17 & 2 & 17 & 10 & 2 & 12 & 10 & 12 & 2 & 13 & 15 & 192 \\
\hline 8. & $\begin{array}{l}\text { View through the } \\
\text { windows of the office }\end{array}$ & 8 & 6 & 10 & 6 & 15 & 14 & 14 & 8 & 9 & 9 & 14 & 7 & 12 & 11 & 5 & 13 & 14 & 11 & 18 & 12 & 7 & 225 \\
\hline 9. & $\begin{array}{l}\text { Distance to } \\
\text { restaurants, shopping, } \\
\text { sport centres, etc. }\end{array}$ & 7 & 12 & 2 & 8 & 6 & 3 & 11 & 3 & 17 & 7 & 15 & 8 & 16 & 13 & 3 & 8 & 3 & 15 & 12 & 11 & 3 & 185 \\
\hline 10. & $\begin{array}{l}\text { Traffic jams on the } \\
\text { way to the office }\end{array}$ & 9 & 14 & 6 & 3 & 2 & 4 & 3 & 5 & 5 & 5 & 16 & 9 & 14 & 12 & 5 & 16 & 16 & 6 & 7 & 16 & 9 & 184 \\
\hline 11. & Size of parking lot & 2 & 5 & 4 & 10 & 3 & 1 & 1 & 2 & 3 & 1 & 4 & 13 & 4 & 1 & 1 & 1 & 8 & 4 & 3 & 10 & 2 & 84 \\
\hline 12. & $\begin{array}{l}\text { Prestige of location } \\
\text { and demand for } \\
\text { location }\end{array}$ & 4 & 1 & 12 & 8 & 5 & 7 & 2 & 1 & 1 & 1 & 3 & 18 & 5 & 2 & 1 & 2 & 4 & 2 & 8 & 17 & 5 & 110 \\
\hline 13. & $\begin{array}{l}\text { Distinction } \\
\text { and prestige of } \\
\text { organizations located } \\
\text { in adjacent buildings }\end{array}$ & 10 & 7 & 5 & 11 & 12 & 9 & 6 & 9 & 6 & 4 & 2 & 17 & 2 & 5 & 8 & 3 & 7 & 8 & 9 & 4 & 6 & 151 \\
\hline 14. & $\begin{array}{l}\text { Noisiness of } \\
\text { environment of the } \\
\text { building }\end{array}$ & 16 & 4 & 15 & 17 & 13 & 10 & 7 & 10 & 10 & 8 & 8 & 5 & 15 & 17 & 9 & 14 & 13 & 13 & 4 & 9 & 17 & 236 \\
\hline 15. & $\begin{array}{l}\text { Visibility of the } \\
\text { building }\end{array}$ & 11 & 15 & 13 & 10 & 14 & 11 & 8 & 15 & 15 & 1 & 5 & 16 & 6 & 9 & 1 & 4 & 2 & 9 & 5 & 1 & 16 & 188 \\
\hline 16. & $\begin{array}{l}\text { Activity of the } \\
\text { business environment }\end{array}$ & 5 & 2 & 17 & 2 & 1 & 5 & 18 & 13 & 8 & 5 & 1 & 12 & 1 & 18 & 3 & 5 & 1 & 1 & 6 & 2 & 1 & 128 \\
\hline 17. & Distance to parking lot & 14 & 10 & 16 & 5 & 8 & 12 & 4 & 11 & 2 & 2 & 6 & 11 & 3 & 15 & 2 & 6 & 11 & 3 & 10 & 3 & 10 & 165 \\
\hline 18. & $\begin{array}{l}\text { Distance to a public } \\
\text { transport stop }\end{array}$ & 15 & 11 & 14 & 6 & 7 & 16 & 5 & 12 & 14 & 3 & 7 & 5 & 7 & 14 & 15 & 18 & 12 & 17 & 11 & 8 & 18 & 236 \\
\hline
\end{tabular}

After ranking the importance of the blocks of indicators, the compatibility with the expert opinions was verified using the criterion $\chi^{2}$. The results of these calculations are presented in Table 5 .

Table 5. Results of the verification of the compatibility with expert assessments of the importance of the office lease indicators

\begin{tabular}{llll}
\hline \multirow{2}{*}{$\begin{array}{l}\text { No. } \\
\text { of indicators }\end{array}$} & \multicolumn{2}{l}{ Value of Pearson criterion $\chi^{2}$} \\
\cline { 3 - 4 } & Calculated & Critical \\
\hline 1 & Economic & 192.90 & 23.68 \\
2 & Premises & 86.13 & 31.45 \\
3 & Environment & 79.54 & 27.59 \\
\hline
\end{tabular}

It can be seen from Table 5 that in all three cases, the calculated value of criterion $\chi^{2}$ is higher than the critical value, which means that the opinions of the experts are compatible.
After verifying the opinions of the experts with the ranks of all three blocks, we can determine the intervals of change of the random value $X$, as well as the number of indicators that are covered by such intervals. We will use the lowest and highest sum of the ranks in every block for this purpose (Table 6).

Table 6. Lowest and highest sums of the ranks for the commercial real estate (office) lease indicators

\begin{tabular}{llll}
\hline \multirow{2}{*}{$\begin{array}{l}\text { No. } \\
\text { of indicators }\end{array}$} & $\begin{array}{l}\text { Lowest and highest sums of } \\
\text { ranks of indicators }\end{array}$ \\
\cline { 3 - 4 } & Lowest & Highest \\
\hline 1 & Economic & 27 & 273 \\
2 & Premises & 90 & 432 \\
3 & Environment & 84 & 292 \\
\hline
\end{tabular}


Now we can determine the size of the intervals based on the formula:

$$
h_{i}=\frac{S_{\max _{i}}-S_{\min _{i}}}{5}
$$

where: $h_{i}$ - interval of the block of indicators $i$; $S_{\max _{i}}$ - highest sum of the ranks of the block of indicators $i$ for all indicators of $i ; S_{\min _{i}}$ - lowest sum of the ranks of the block of indicators $i$ for all values of this block.

The rank change interval $S_{\max _{i}}-S_{\min _{i}}$ is divided into five parts, so that after finally combining all three blocks of indicators every interval will contain not less than 5 indicators.

Now the blocks of indicators can be grouped according to their intervals (Tables 7-9).

The results of the grouping of the indicators for all three blocks are presented in Table 10.

The elimination of insignificant indicators from the list is based on a histogram obtained by placing the values of the indicators at certain intervals and determining the frequency that those indicators were mentioned. Its configuration is thus also the theoretical probability distribution of the random value $X$, and its description largely depends on the manner of grouping of the results of the ranking of the indicators. In order to draw up a histogram, first of all we need to rank the indicators of all three blocks according to their importance, giving rank 1 to the most important indicator and rank $n$ to the least important indicator (where $n$ is the number of indicators in a block). The value $X$ shows the number of times that the indicator was mentioned in the expert questionnaires $(0 \leq X \leq Z$, where $Z$ is the number of experts).

Based on Tables 7-10, a histogram of the importance of the economic, premises and environment indicators can be drawn up (Figs. 2-4).

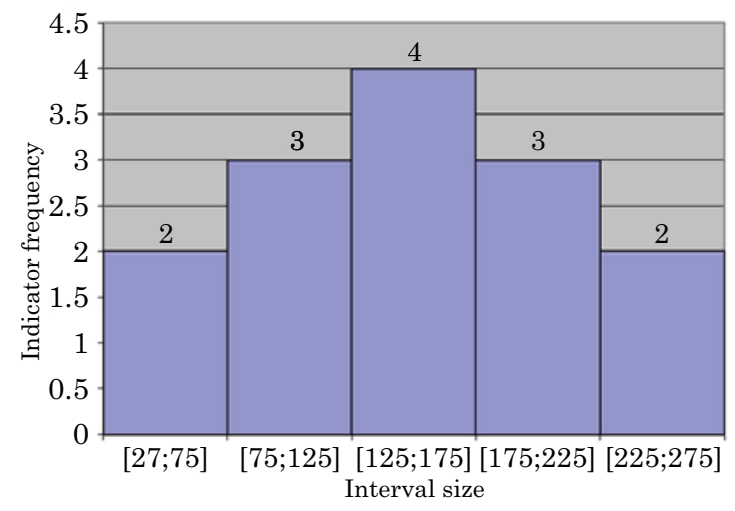

Fig. 2. Histogram of the distribution

of the importance of the economic lease indicators

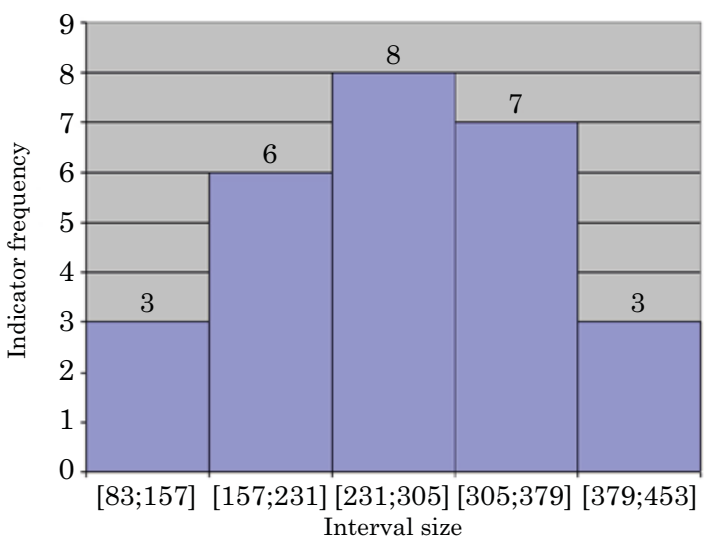

Fig. 3. Histogram of the importance of the premises indicators

Table 7. Results of the grouping of the economic lease indicators

\begin{tabular}{llllll}
\hline Intervals & {$[27.75]$} & {$[75.125]$} & {$[125.175]$} & {$[175.225]$} & {$[225.275]$} \\
\hline Frequency & 2 & 3 & 4 & 3 & 2 \\
\hline
\end{tabular}

Table 8. Results of the grouping of the premises indicators

\begin{tabular}{llllll}
\hline Intervals & {$[83.157]$} & {$[157.231]$} & {$[231.305]$} & {$[305.379]$} & {$[379.453]$} \\
\hline Frequency & 3 & 6 & 8 & 7 & 3 \\
\hline
\end{tabular}

Table 9. Results of the grouping of the environment indicators

\begin{tabular}{llllll}
\hline Intervals & {$[82.124]$} & {$[124.166]$} & {$[166.208]$} & {$[208.250]$} & {$[250.292]$} \\
\hline Frequency & 2 & 3 & 7 & 3 & 2 \\
\hline
\end{tabular}

Table 10. Results of the grouping of the lease indicators according to their importance

\begin{tabular}{|c|c|c|c|c|c|c|c|c|c|c|c|}
\hline \multirow{3}{*}{$\begin{array}{l}\text { Name of block } \\
\text { of indicators }\end{array}$} & \multicolumn{10}{|c|}{ Interval number } & \multirow[t]{3}{*}{ Total } \\
\hline & \multicolumn{2}{|c|}{ One } & \multicolumn{2}{|l|}{ Two } & \multicolumn{2}{|l|}{ Three } & \multicolumn{2}{|l|}{ Four } & \multicolumn{2}{|l|}{ Five } & \\
\hline & $\begin{array}{l}\text { Interval } \\
\text { limits }\end{array}$ & $\begin{array}{l}\text { Fre- } \\
\text { quency }\end{array}$ & $\begin{array}{l}\text { Interval } \\
\text { limits }\end{array}$ & $\begin{array}{l}\text { Fre- } \\
\text { quency }\end{array}$ & $\begin{array}{l}\text { Interval } \\
\text { limits }\end{array}$ & $\begin{array}{l}\text { Fre- } \\
\text { quency }\end{array}$ & $\begin{array}{l}\text { Interval } \\
\text { limits }\end{array}$ & $\begin{array}{l}\text { Fre- } \\
\text { quency }\end{array}$ & $\begin{array}{l}\text { Interval } \\
\text { limits }\end{array}$ & $\begin{array}{l}\text { Fre- } \\
\text { quency }\end{array}$ & \\
\hline Economic & {$[27.75]$} & 2 & [75.125] & 3 & {$[125.175]$} & 4 & [175.225] & 3 & {$[225.275]$} & 2 & 14 \\
\hline Premises & [83.157] & 3 & [157.231] & 6 & [231.305] & 8 & [305.379] & 7 & [379.453] & 3 & 27 \\
\hline Environment & [82.124] & 2 & [124.166] & 3 & [166.208] & 7 & [208.250] & 3 & {$[250.292]$} & 2 & 17 \\
\hline
\end{tabular}




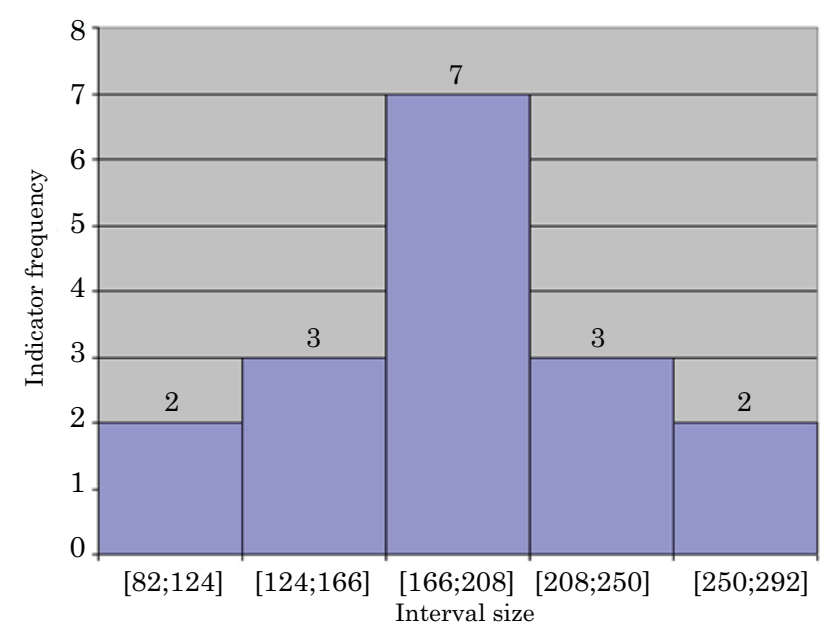

Fig. 4. Histogram of the importance of the environment indicators

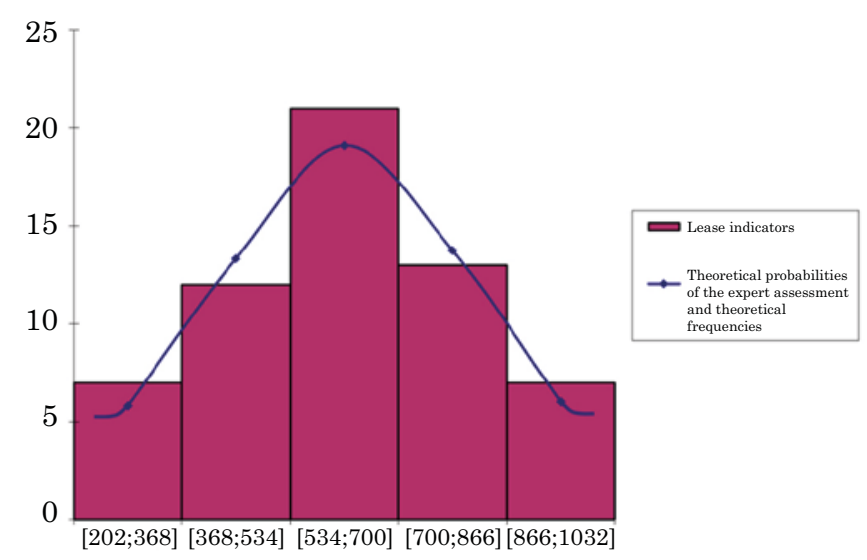

Fig. 5. Histogram of the expert assessments of the importance of the lease indicators and their theoretical distribution

Table 11. Collective results of the ranking of the importance of the lease indicators

\begin{tabular}{lllllll}
\hline Intervals & {$[202.368]$} & {$[368.543]$} & {$[543.700]$} & {$[700.866]$} & [866.1032] & Total \\
\hline Frequency & 7 & 12 & 19 & 13 & 7 & 58 \\
\hline
\end{tabular}

Now we can draw up a collective histogram of the importance of the lease indicators. For this purpose, we need to start by determining the collective results of the ranking of the importance of the indicators, and then to determine the size of the intervals and the total number of indicators covered by the intervals based on the formula (1) (Table 11).

Based on Table 11, we can draw up a collective histogram of the importance of the lease indicators (Fig. 5).

As can be seen from Table 11, every interval contains at least 5 indicators. We can also see that a hypothesis that the random value $X$ is distributed according to a normal distribution can be presented. Based on this table, we can calculate the parameters of the distribution - mean $\bar{X}$ and average square deviation $S$. From this, we determined that $\bar{X}=619.6$ and $S=196$. Based on the table of the normal distribution, we calculated theoretical probability $P_{i}$ that the random value $X$ belongs to a certain interval $\left(X_{i-1}, X_{i}\right)$, and the theoretical frequencies $n_{i}^{*}=n p_{i}$. The results of the calculations are presented in Table 12.

Table 12. Theoretical probability and theoretical frequencies of the expert assessment of the importance of the lease indicators

\begin{tabular}{llllll}
\hline $\begin{array}{l}\text { Theoretical } \\
\text { probability }\end{array}$ & 0.1003 & 0.2297 & 0.3291 & 0.2371 & 0.1038 \\
\hline $\begin{array}{l}\text { Theoretical } \\
\text { frequencies }\end{array}$ & 5.82 & 13.32 & 19.09 & 13.75 & 6.02 \\
\hline
\end{tabular}

The theoretical frequencies of all lease indicators are presented in Figure 5. Now we need to verify whether the hypothesis that the importance of the commercial real estate object (office) lease is distributed according to a normal distribution is correct. For this purpose, we needed to calculate the actual and critical values of the criterion $\chi^{2}$ with the degrees of freedom $\mathrm{Y}=\mathrm{k}-3-1=2$ and the level of significance $\alpha=0.05$. The results are $\chi_{f}^{2}=5.99$ and $\chi_{k r}^{2}=0.574$

The calculated value $\chi^{2}$ is higher than the critical value; therefore, the hypothesis that the value $X$ is distributed according to a normal distribution with the mean of $X=619.6$ and the average square deviation $S=196$ is accepted. This shows which indicators from the last intervals may be eliminated. For this purpose, we need to determine the percentage of unnecessary indicators to be eliminated. If we assume that this number is $10 \%$ (i.e. the level of significance $a=0.1$ ), then by applying the inequality $P\left(X_{k r} \leq X \leq+\infty\right)=0.1$ from the normal distribution table, we can determine that $X_{k r}=870.48$, i.e. the indicators whose sum of their ranks is higher than 870.48 should be eliminated from the general list of indicators. These are the indicators from the last interval (Fig. 5). They include 2 indicators from the economic block, 3 indicators from the premises block and 2 indicators from the environment block.

The final list of indicators to be included in the system for commercial real estate object (office) leasing is as follows (Table 13). 
Table 13. System of indicators for commercial real estate object (office) leasing

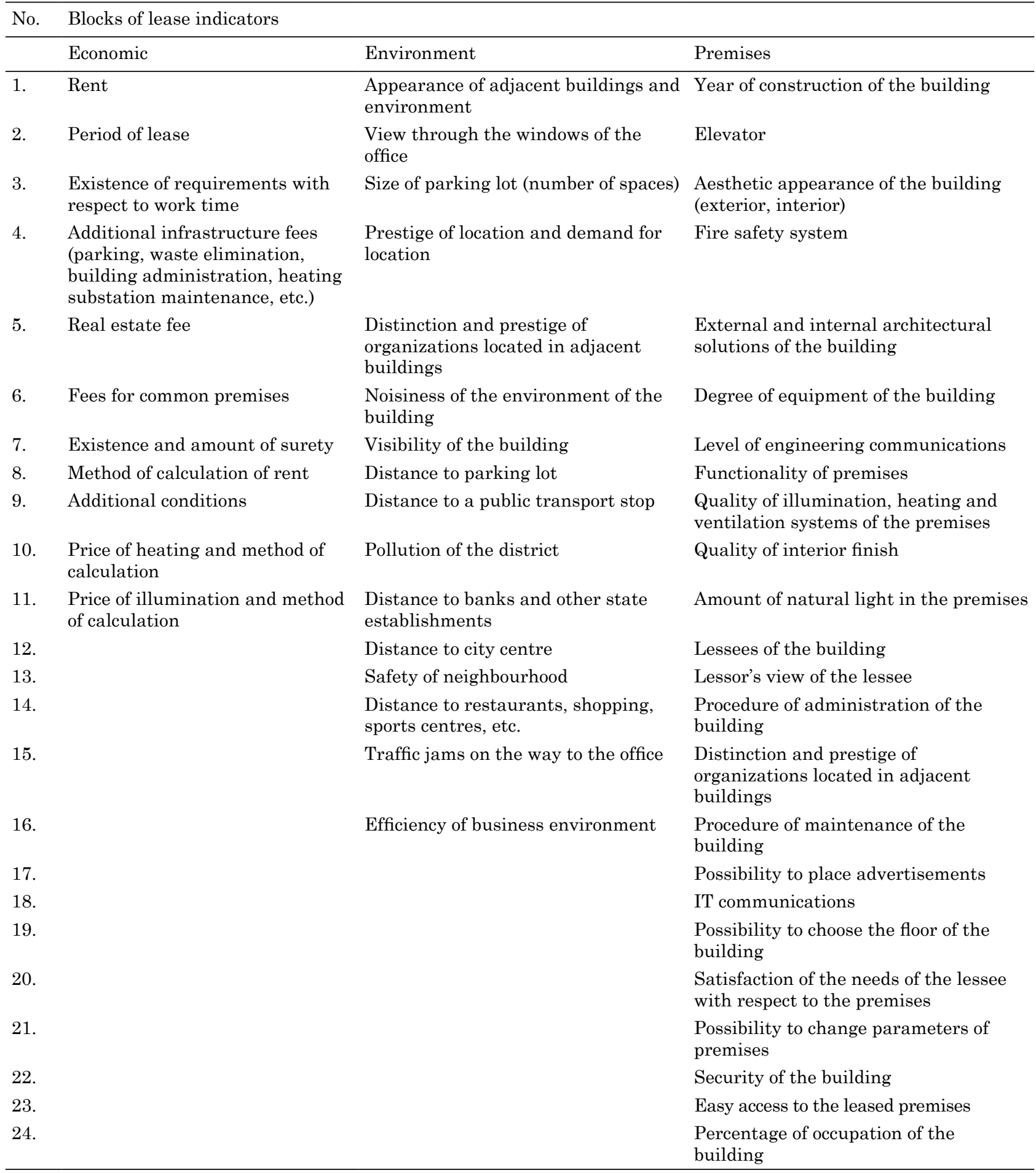

Table 13 shows the blocks of 11 economic lease indicators, 16 environment indicators and 24 premises indicators.

This system of indicators needs to be adapted for a multicriteria assessment. This necessity arises due to the fact that we need to know not only the values of the indicators, but also their weights. This is determined by the experts. The accuracy of an expert assessment largely depends on the number of assessed indicators. Where there are not many indicators, the experts can determine their weights quite accurately. However, when their number increases, it becomes more difficult to determine the interrelation of the weights of the indicators with respect to the analyzed phenomenon. This increases the incompatibility of the expert opinions. We can see without proof that an expert can assess the weights of 10-12 indicators 
rather accurately (Ginevičius 2006). The system of indicators presented in Table 12 does not satisfy such conditions; thus, it should be transposed in a manner so that the number of assessed indicators does not exceed the desired number (Ginevičius 2007a, 2007b, 2009).

\section{CONCLUSIONS}

The adequacy of a multicriteria assessment largely depends on the system of indicators that reflects the analyzed phenomenon. It is formed on the basis of a list of indicators. The system of indicators should contain not too many and not too few indicators. Otherwise, the accuracy of the multicriteria assessment will decrease.

Based on the literature and other sources, a list of 59 indicators for commercial real estate object (office) leasing was compiled. In order to form an accurate system of indicators for leasing, the insignificant indicators had to be eliminated. This was done by applying the methods of mathematical statistics.

The formation of the system of lease indicators was based on the table specifying the names of the indicators, as well as on the frequency that each indicator was mentioned. The elimination of indicators from the list was then done in the following order: the value $X$ was chosen as being similar to the distribution of the frequencies in the table; the interval of change of this value was determined; a histogram of the value $X$ was drawn up; depending on the form of the histogram a theoretical probability distribution was chosen; the parameters of the chosen probability distribution were then calculated (with mean and average square deviations); based on these parameters, the function of the probability distribution $F(x)$ or the density $f(x)$ was determined; the calculation of the theoretical probability $P_{i}$ that the random value $X$ belongs to any interval $\left(X_{i-1}, X_{i}\right)$ was performed: i.e. the calculation of the respective theoretical frequencies; the statistical hypothesis that the random value $X$ was distributed according to the respective theoretical distribution was verified; and depending on the chosen degree of significance we determined the indicators that needed to be eliminated, as they were insignificant. It was determined that 2 indicators from the economic block, 3 indicators from the premises block and 2 indicators from the environment block could be eliminated from the general list of lease indicators as insignificant.

The theoretical benefit of this article is the suggestion of an adequate method for the formation of the system of indicators for commercial real estate object (office) leasing that is intended to solve the problem of office leasing. The method allows businessmen to more accurately assess the office leasing options which are the most suitable.

Even though the current study has presented several advantages, there are some limitations as well. The indicators need to be determined by means of an expert evaluation, which introduces a certain element of subjectivity.

\section{REFERENCES}

Au-Yong, C. P.; Ali, A. S.; Ahmed, F. 2014. Improving occupants'satisfaction with effective maintenance management of HVAC system in office buildings, Automation in Construction 43: 31-37. http://dx.doi. org/10.1016/j.autcon.2014.03.013

Azbainis, V.; Rudzkiene, V. 2011. Evaluation of impact of transition and economic crises of real estate market, Business: Theory and Practice 12(2): 150-161. http://dx.doi.org/10.3846/btp.2013.20

Ball, M.; Lizieri, C.; McGregor, B. 2012. The economics of commercial property markets. Routledge.

Bausys, R.; Zavadskas, E. K. 2015. Multicriteria decision making approach by VIKOR under interval neutrosophic set environment, Economic Computation and Economic Cybernetics Studies and Research 49(4): 33-48.

Boggia, A.; Cortina, C. 2010. Measuring suitainable development using a multicriteria model: a case study, Journal of Environmental Management 91(11): 23012306. http://dx.doi.org/10.1016/j.jenvman.2010.06.009

Brauers, W. K. M.; Ginevičius, R.; Podviezko, A. 2014. Development of a methodology of evaluation of financial stability of commercial banks, Panoeconomics LXI(3): 344-367. http://dx.doi.org/10.2298/ PAN1403349B

Buracas, A.; Zvirblis, A.; Joksiene, I. 2012. Measurement of entrepreneurship macro surrounding advantages: country's economic competitiveness approach, Inzinerine Ekonomika-Engineering Economics 23(1): 5-13. http://dx.doi.org/10.5755/j01.ee.23.1.1219

Čeh, M.; Viitanen, K.; Peruš, I. 2012. A non-parametric CAE approach to office rents: identification of Helsinki metropolitan area submarkets, Expert Systems with Applications 39(1): 460-471. http://dx.doi. org/10.1016/j.eswa.2011.07.037

French, N.; Wiseman, G. 2003. The price of space: the convergence of value in use and value in exchange, Journal of Property Investment \& Finance 21(1): 23-30. http://dx.doi.org/10.1108/14635780310468284

Ginevičius, R. 2006. Multicriteria evaluations of the criteria weights based on their interrelationship, Business: Theory and Practice 7(1): 3-13. http://dx.doi. org/10.3846/btp.2006.01

Ginevičius, R. 2007a. Hierarchical structuring of processes and phenomena, Business: Theory and Practice 8(1): 14-18. 
Ginevičius, R. 2007b. Generating a structured system of cryteria for describing a complicated phenomenon, Business: Theory and Practice 8(2): 68-72.

Ginevičius, R. 2009. Some problems of quantitative evaluations of the state of social - economic systems, Business: Theory and Practice 10(2): 69-83. http://dx.doi.org/10.3846/1648-0627.2009.10.69-83

Ginevičius, R.; Podvezko, V. 2005. Generations of a set of evaluations criteria, Business: Theory and Practice 4: 199-207.

Ginevičius, R.; Podvezko, V.; Podvezko, A.; Ginevičius, T. 2013. On creating a system of criteria for multiple criteria evaluations using methods of matematical statistics, in $14^{\text {th }}$ German - Lithuanian - Polish Colloquium, 15 May 2013, Vilnius, Lithuania. Vilnius: Technika, 64-71.

Ginevičius, R.; Podviezko, A. 2013. The evaluation of financial stability and soundness of Lithuanian banks, Ekonomska Istrazivanja-Economic Research 26(2): 191-208.

Golusin, M.; Munitlak Ivanović, O. 2009. Definition, characteristics and state of suitainable development in countries of Southeastern Europe, Agriculture, Ecosystems and Environment 130(1-2): 67-74. http://dx.doi.org/10.1016/j.agee.2008.11.018

Hashemkhani Zolfani, S.; Maknoon, R.; Zavadskas, E. K. 2016. An introduction to prospective multiple attribute decision making (PMADM), Technological and Economic Development of Economy 22(2): 309-326. http://dx.doi.org/10.3846/20294913.2016.1150363

Joksiene, I.; Zvirblis, A. 2014. Consolidated assessment of composite competitiveness indicators: the case of manufacturing enterprise, in $8^{\text {th }}$ International Scientific Conference "Business and Management 2014", 15-16 May 2014, Vilnius, Lithuania. Vilnius: Technika, 59-66. http://dx.doi.org/10.3846/bm.2014.009

Keshavarz Ghorabaee, M.; Zavadskas, E. K.; Olfat, L.; Turskis, Z. 2015. Multi-criteria inventory classification using a new method of evaluation based on distance from average solution (EDAS), Informatica 26(3): 435-451. http://dx.doi.org/10.15388/Informatica.2015.57

Kim, Y.; Park, D.; Um, M.-J.; Lee, H. 2015. Prioritizing alternatives in strategic environmental assessment (SEA) using VIKOR method with random sampling for data gaps, Expert Systems with Applications 42(22): 8550-8556. http://dx.doi.org/10.1016/j. eswa.2015.07.010

Kondyli, J. 2010. Measurement and evaluation of suitainable development: a composite indicator for the Islands of the North Aegean region, Greece, Environmental Impact Assessment Review 30(6): 347-356. http://dx.doi.org/10.1016/j.eiar.2009.08.006
Kou, G.; Ergu, D.; Lin, C.; Chen, Y. 2016. Pairwise comparison matrix in multiple criteria decision making, Technological and Economic Development of Economy 22(5): 738-765. http://dx.doi.org/10.3846/202949 13.2016.1210694

Liu, Y.; Fan, Z.-P.; Zhang, X. 2016. A method for large group decision-making based on evaluation information provided by participators from multiple groups, Information Fusion 29: 132-141. http://dx.doi. org/10.1016/j.inffus.2015.08.002

Mardani, A.; Jusoh, A.; Nor, K. M. D.; Khalifah, Z.; Zakwan, N.; Valipous, A. 2015a. Multiple criteria decision-making techniques and their applications - a review of the literature from 2000 to 2014, Ekonomska Istrazivanja-Economic Research 28(1): 516-571. http://dx.doi.org/10.1080/1331677X.2015.1075139

Mardani, A.; Jusoh, A.; Zavadskas, E. K.; Khalifah, Z.; Nor, K. M. 2015b. Application of multiple-criteria decision-making techniques and approaches to evaluating of service quality: a systematic review of the literature, Journal of Business Economics and Management 16(5): 1034-1068. http://dx.doi.org/10.3846/ 16111699.2015.1095233

Nase, I.; Berry, J.; Adair, A. 2013. Real estate value and quality in commercial office properties, Journal of European Real Estate Research 6(1): 48-62. http://dx.doi.org/10.1108/17539261311312988

Nugaras, J.; Ginevičius, R. 2015. The strategic assessment of networking of a higher educational institutions, Ekonomska Istrazivanja-Economic Research 28(1): 31-44. http://dx.doi.org/10.1080/13316 77X.2014.995963

Pagourtzi, E.; Assimakopoulos, V.; Hatzichristos, T.; French, N. 2003. Real estate appraisal: a review of valuation methods, Journal of Property Investment \& Finance 21(4): 383-401. http://dx.doi. org/10.1108/14635780310483656

Podvezko, V. 2008. Comprehensive evaluation of complex quantities, Business: Theory and Practice 9(3): 160-168. http://dx.doi.org/10.3846/1648-0627.2008.9.160-168

Russell, S. 2002. The dynamics of property locationvalue and the factors which drive the location of shops, offices and other land uses. London: Taylor \& Francis.

Turskis, Z.; Zavadskas, E. K.; Peldschus, F. 2009. Multi-criteria optimization systems for decision making in construction design and management, Inzinerine Ekonomika-Engineering Economics 61(1): 7-18.

Zavadskas, E. K.; Turskis, Z. 2011. Multiple criteria decision making (MCDM) methods in economics: an overview, Technological and Economic Development of Economy 17(2): 397-427. http://dx.doi.org/10.3846 /20294913.2011.593291 